\title{
Fertility Status of Soils and Improved Crop Productivity through Balanced Nutrition in Rainfed Watershed of India - a GIS based Study
}

\author{
Sarika P. Karda ${ }^{1}$, Gauri M. Rane ${ }^{2}$ \\ ${ }^{1}$ Research Scholar, Department of Environmental Sciences, KCES's Moolji Jaitha College, Jalgaon, India \\ ${ }^{2}$ Head, Department of Botany, KCES's Moolji Jaitha College, Jalgaon, India
}

\begin{abstract}
Rain-fed agriculture productivity is crucial for food security and economy of the state. To characterize the fertility status of soils under dry-land agriculture in the semi-arid regions, 110 soil samples were collected from Nagulapally-Konapur Model Watershed area in Medak district of Telangana to diagnose the deficiencies of macronutrients like Potassium, Sodium and Sulphur and micronutrients like Boron and Zinc. A summary of the chemical analysis of soil samples covering the watershed area showed that the farmer's fields sampled had a wide range in $\mathrm{pH}$ and EC and they were low-to-moderate in organic carbon, generally adequate in exchangeable potassium and sodium. However, the most revealing results on soil chemical analysis were the widespread deficiencies of levels of extractable phosphorous $(P)$, sulphur $(S)$, boron $(B)$ and zinc $(\mathrm{Zn})$ in the samples. GIS mapping of the estimated fertility parameters was carried out using Arc GIS software to understand the occurrence of deficiencies of micronutrients over the watershed area under study. On-farm participatory trials were conducted for selected rainfed crops to study the impact of balanced nutrition $(B N)$ on crop productivity over farmers practise (FP).
\end{abstract}

Keywords- Agriculture, Fertility, Macronutrients, Micronutrients, GIS.

\section{INTRODUCTION}

Semi Arid Tropics (SAT) regions spread over 1.16 billion hectares in the developing world, are densely populated and poverty stricken, largely as a result of dependence of the economy and livelihoods on subsistence agriculture (Srinivasarao et. al., 2008). Soils in the Indian SAT are marginal compared to irrigated soils. Poor soils are brought under cultivation due to population pressure. It is, however, recognized and emphasized that the productivity of SAT soils is low due to water shortage. Apart from water shortage, low fertility is also an issue because it constraints crop productivity in the SAT regions of India; but in practice the deficiencies of major nutrients $(\mathrm{N}$ and P) are considered important. (Sahrawat et.al. 2007). Rain-fed agriculture productivity is crucial for food security and economy of the state. To achieve foods security, minimize water conflicts and reduce poverty it is essential to increase productivity of rainfed systems by harnessing the existing potential (Wani et al., 2003a).

To analyse the general fertility status of soils in rain-fed systems and to study the change in economic crops in response to addition of deficient nutrients over farmer's practice, soil samples were collected from NagulapallyKonapur Model Watershed, Medak District, Telangana. Based on the soil test results, on-farm participatory trials were planned and conducted with the farmers to evaluate and demonstrate the effects of balanced nutrition on crop productivity.

\section{METHODOLOGY}

Soil samples from agricultural fields in Nagulapally and Konapur villages of the watershed under study were collected by adopting stratified random sampling along the toposequence. To diagnose the deficiencies of macronutrients like Potassium, Sodium and Sulphur and micronutrients like Boron and Zinc in the soils of watersheds under study, soil testing was carried out using following methods -

Table.1: Different methods used for diagnosis of fertility parameters of soil samples

\begin{tabular}{|c|c|}
\hline $\begin{array}{l}\text { Soil } \\
\text { Property }\end{array}$ & Description \\
\hline $\mathrm{pH}$ & $\begin{array}{l}\text { Soil to water ratio of } 1: 2 \text { using glass } \\
\text { electrode }\end{array}$ \\
\hline EC & Same as above, using EC meter \\
\hline $\begin{array}{l}\text { Organic } \\
\text { Carbon (OC) }\end{array}$ & $\begin{array}{l}\text { Wet dichromate oxidation (Nelson } \\
\text { \& Sommers 1996) }\end{array}$ \\
\hline Avail P & $\begin{array}{l}\text { Olsen P }\left(0.5 \mathrm{M} \mathrm{NaHCO}_{3}, \mathrm{pH} 8.5\right) \\
\text { (Olsen \& Sommers } 1982)\end{array}$ \\
\hline $\begin{array}{l}\text { Avail Na \& } \\
\mathrm{K}\end{array}$ & $\begin{array}{l}\text { 1N ammonium acetate (Helmke \& } \\
\text { Sparks 1996) }\end{array}$ \\
\hline Avail S & $\begin{array}{l}\mathrm{CaCl}_{2} / \mathrm{MCP} \text { extraction (Tabatabai } \\
1996 \text { ) }\end{array}$ \\
\hline Avail Zn & $\begin{array}{l}\text { DTPA extractable Zn (Lindsay and } \\
\text { Norvell 1978) }\end{array}$ \\
\hline Avail B & $\begin{array}{l}\text { Hot water extractable B (Keren } \\
\text { 1996) }\end{array}$ \\
\hline
\end{tabular}


Arc GIS 9.3 software was used for spatial and non-spatial database generation and for preparation of spatial distribution maps by inverse distance weighted (IDW) method. Based on the attribute database of the soil quality, the mapping of physico-chemical analysis was carried out and area under nutrient deficiency was calculated using Reclassify tool in Arc GIS 10.3 in which the critical limits of the nutrients were added in IDW maps to class the deficient and non-deficient soil samples. Based on the soil testing analysis, soil-test based fertilizer recommendations were developed at block/village level for balanced nutrient management. Full dose of a nutrient was recommended if $>50 \%$ deficiency was observed and half dose of nutrients if deficiency was observed $<50 \%$ based on the critical limits of various nutrients in the soil. On-farm participatory trials were conducted with the farmers to evaluate and demonstrate the effects of balanced nutrition on crop productivity in rainy season. Common rainfed crops such as tomato, chillies, turmeric, cotton, paddy and red gram that are usually grown in the watershed are were selected for the treatments.
Two treatments were conducted -

1. Farmer's practice (FP, application of N, P \& K)

2. Balanced nutrition (BN, applications of N, P, K plus $S$,

$\mathrm{B} \& \mathrm{Zn})$

DAP ( diammonium phosphate) - N \& P, Gypsum - S,

Zinc Sulphate - Zn, Agribor - B

\section{RESULTS AND DISCUSSIONS}

The soil test results for $\mathrm{pH}, \mathrm{EC}$, Organic C, extractable $\mathrm{P}$, $\mathrm{K}, \mathrm{Na}, \mathrm{S}, \mathrm{B}$ and $\mathrm{Zn}$ of soil samples collected from farmer's fields in the semi-arid watershed comprising of two villages Nagulapally and Konapur located in Medak district of Indian state of Telangana (110 farmer's fields) showed that the results varied with villages in the watershed and had a wide range in soil chemical characteristics analyzed to evaluate the fertility status of farmer's fields. The farmer's fields that are selected and sampled for soil testing are shown in figure 5.12 with map of watershed prepared in Arc GIS 10.3.

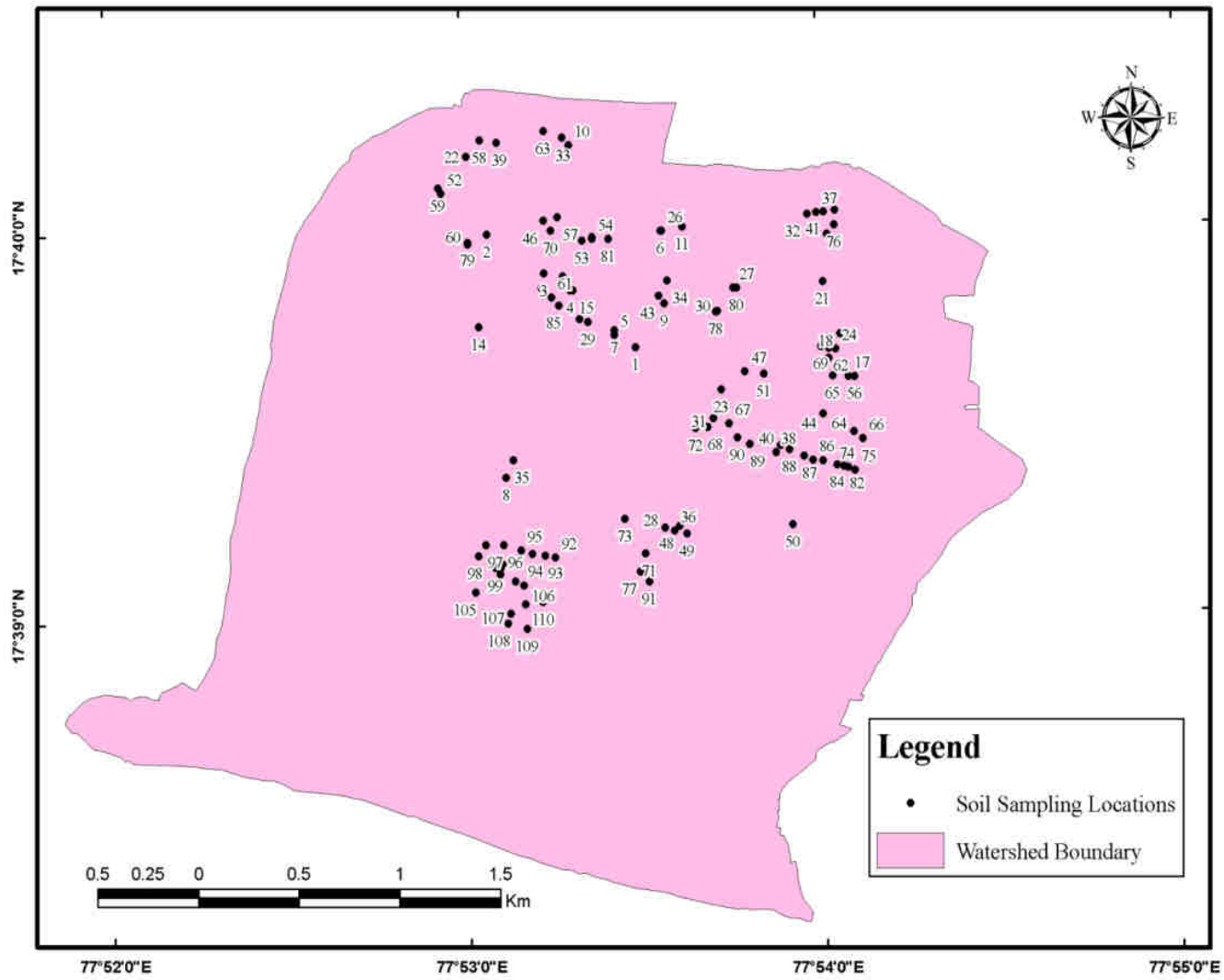

Fig.1: Soil sampling locations in Nagulapally-Konapur Model Watershed, Medak, Telangana

The overall results of soil samples collected from 110 farmer's fields in Nagulapally-Konapur watershed of Medak district are presented in Table 2. The statistical measures range, mean, $\%$ of samples deficient and area of watershed under deficiency are shown below. The estimated soil fertility parameters were taken into GIS environment and the extent of occurrence of deficiencies of essential nutrients were mapped spatially to identify the deficient and critical fields in the watershed. 
Table.2 Soil fertility status of farmer's field in Nagulapally-Konapur model watershed

\begin{tabular}{|c|c|c|c|c|c|c|c|c|c|}
\hline \multicolumn{10}{|c|}{ Sample Count - 110} \\
\hline Parameter & pH & $\begin{array}{c}\mathrm{EC} \\
\mathrm{dSm}^{-1}\end{array}$ & $\begin{array}{c}\text { Org C } \\
\%\end{array}$ & $\begin{array}{c}\text { Ols-P } \\
\text { mgkg }^{-1}\end{array}$ & $\begin{array}{l}\text { Exch-K } \\
\text { mgkg }^{-1}\end{array}$ & $\begin{array}{c}\text { Exch-Na } \\
\text { mgkg }^{-1}\end{array}$ & $\begin{array}{c}\text { Avail-S } \\
\text { mgkg }^{-1}\end{array}$ & $\begin{array}{l}\text { Avail-B } \\
\text { mgkg }^{-1}\end{array}$ & $\begin{array}{c}\text { Avail-Zn } \\
\text { mgkg }^{-1}\end{array}$ \\
\hline Range & $5.1-8.7$ & $0.1-0.8$ & $0.1-1.6$ & $0.1-13.6$ & $73-544$ & $50-492$ & $2.5-925$ & $0.2-1.5$ & $0.5-80$ \\
\hline Mean & 8.04 & 0.17 & 1.17 & 2.02 & 247.40 & 123.83 & 18.06 & 0.61 & 2.07 \\
\hline \% deficiency & & & 4 & 95 & 0 & 0 & 84 & 53 & 42 \\
\hline Area Deficiency (ha) & & & 0.57 & 1181 & 0 & 0 & 972.35 & 441.48 & 349.85 \\
\hline
\end{tabular}

The $\mathrm{pH}$ of the soil samples ranged from $5.1-8.7$ indicating some samples with acidic $\mathrm{pH}$ with a mean of 8.04 showing alkaline nature of soils (Figure 2). The EC content reflects the amount of soluble salts present in the soils. The EC values ranged from $0.1 \mathrm{dSm}^{-1}$ to $0.8 \mathrm{dSm}^{-1}$ with mean of $0.17 \mathrm{dSm}^{-1}$ (Figure 3). Very low deficiency of only $4 \%$ was observed with organic $C$ concentration which is generally considered as source of $\mathrm{N}$. The organic $\mathrm{C}$ values ranged from $0.1 \%$ to $1.6 \%$ with mean of $1.17 \%$. Figure 4 shows spatial distribution map of organic carbon with 0.57ha area under deficiency. Phosphorous deficiency was prominent in the watershed with $\mathbf{9 5 \%}$ of fields showing $\mathrm{P}$ deficiency. This may be due to excessive use of organic phosphatic fertilizers by the farmer's inputs. The extractable $\mathrm{P}$ values ranged from $0.1 \mathrm{mgkg}^{-1}$ to $13.6 \mathrm{mgkg}^{-1}$ with average of $2.02 \mathrm{mgkg}^{-1}$. Out of $1185 \mathrm{ha}$ area of watershed, 1181 ha is observed to be deficient with $\mathrm{P}$ content (Figure 5). The extractable $\mathrm{K}$ and $\mathrm{Na}$ concentrations were in sufficient amounts and all the farmer's fields analyzed showed adequate amounts and as such were not a problem in any of the soil samples. The extractable $\mathrm{K}$ ranged from $73 \mathrm{mgkg}^{-1}$ to $544 \mathrm{mgkg}^{-1}$ with mean of $247.40 \mathrm{mgkg}^{-1}$ (Figure 6). Na concentrations in the soil samples fluctuated from $50 \mathrm{mgkg}^{-1}$ to $492 \mathrm{mgkg}^{-}$ ${ }^{1}$ with an average value of $123.83 \mathrm{mgkg}^{-1}$. Figure 7 shows the spatial distribution map of $\mathrm{Na}$ with adequate amounts in all the farmer's fields. In addition to macronutrient deficiency, the analysis results showed a widespread deficiency of secondary and micronutrients in terms of S, $\mathrm{B}$ and $\mathrm{Zn}$. Sulphur deficiency was found in majority of the fields with $\mathbf{8 4 \%}$ of total samples have low concentrations of extractable $\mathrm{S}$. The sulphur values ranged between $2.5 \mathrm{mgkg}^{-1}$ to $925 \mathrm{mgkg}^{-1}$ with mean of $18.06 \mathrm{mgkg}^{-1}$ (Table 2). About 972.35ha of area of watershed was observed under S deficiency shown with light and dark color codes in figure $8.53 \%$ of samples were estimated with boron deficiency with boron concentration ranging from $0.2 \mathrm{mgkg}^{-1}-1.55 \mathrm{mgkg}^{-1}$ with

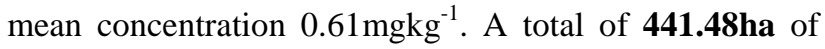
area out of 1185 ha of total watershed area was found to be deficient with boron micronutrient (Figure 9). As compared to other micronutrients, $\mathrm{Zn}$ concentration deficiency was observed low showing $\mathbf{4 2 \%}$ of soil samples analyzed were deficient. Very low values fluctuating between $0.55 \mathrm{mgkg}^{-1}$ to $805 \mathrm{mgkg}^{-1}$ with average $\mathrm{Zn}$ concentration of $2.07 \mathrm{mgkg}^{-1}$ was observed and about 349.85ha of total area was found to $b$ deficient. Figure 10 clearly demonstrates the spatial distribution of the regions of farmer's field having $\mathrm{Zn}$ deficiency.

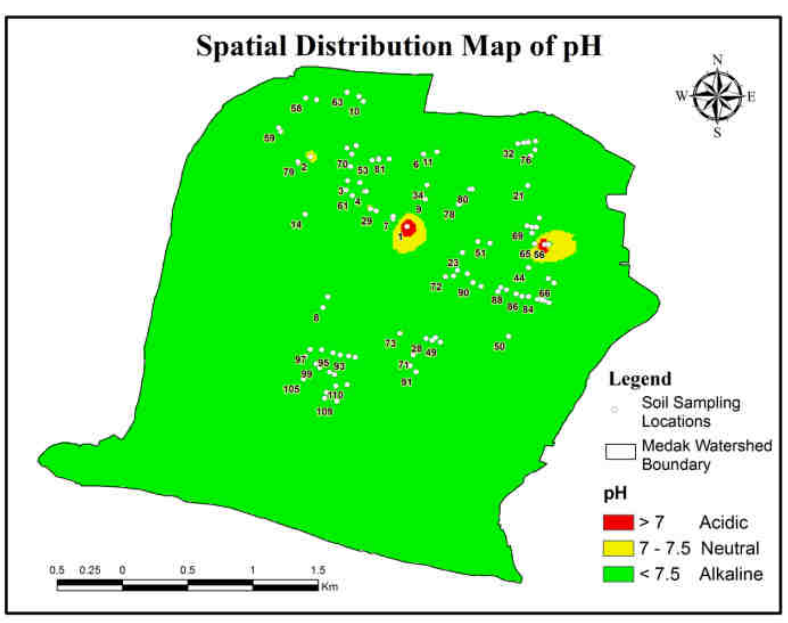

Fig. 2

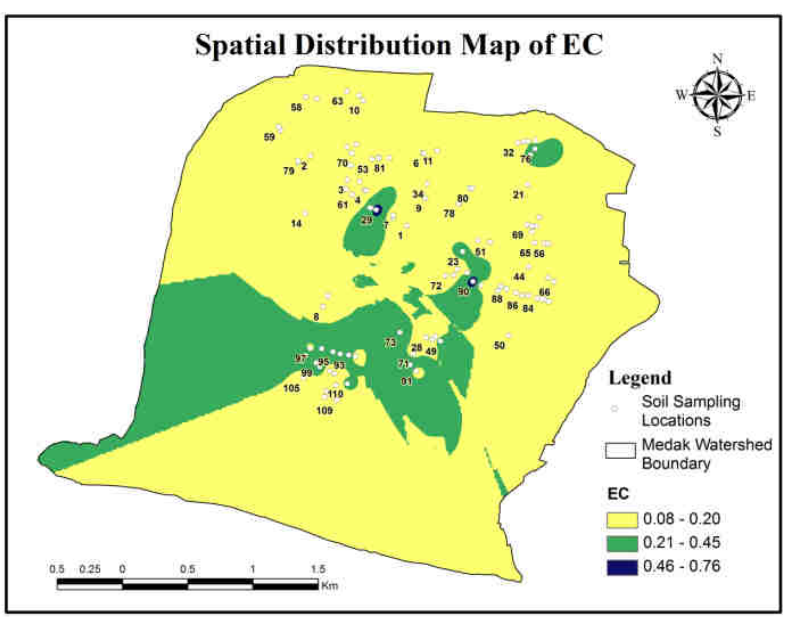

Fig.3 


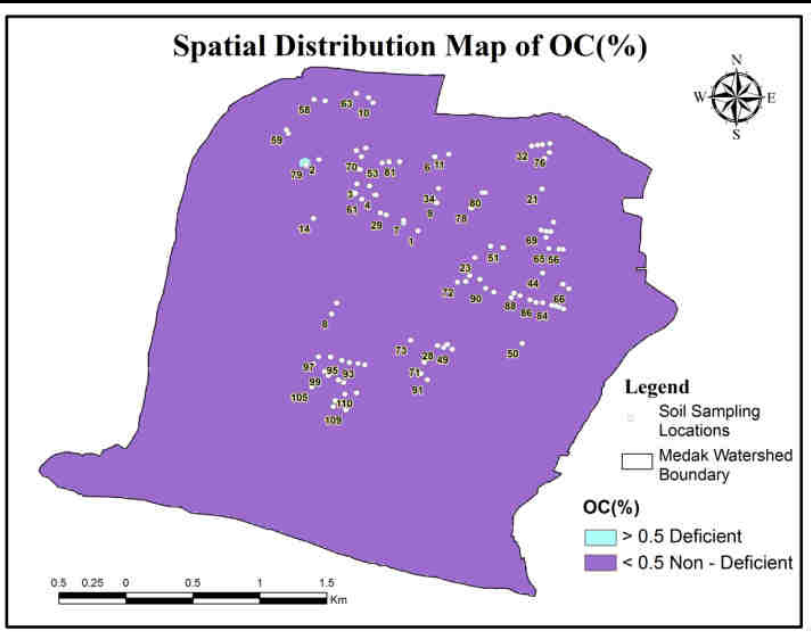

Fig.4

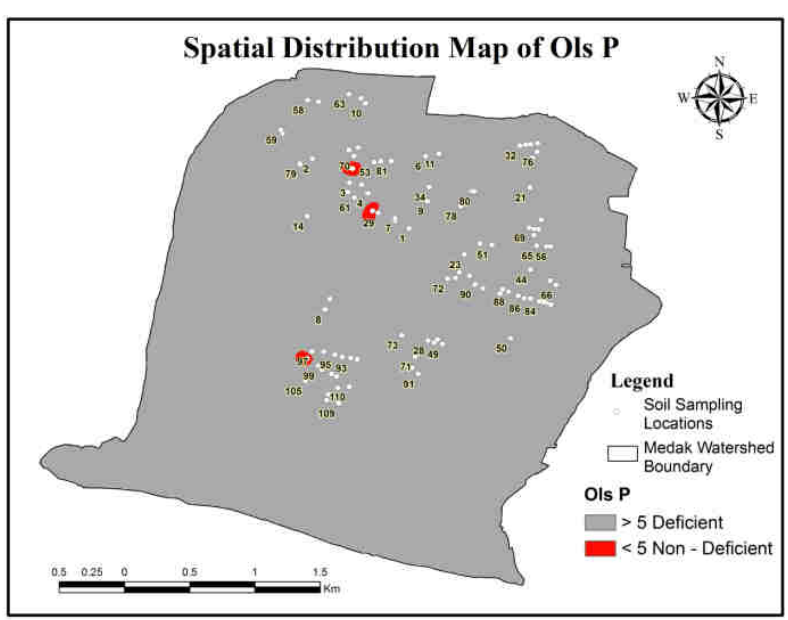

Fig.5

The results clearly highlights the wide range of macro, secondary and micronutrients over the study region and widespread deficiencies of these essential nutrient that may have impact on the production and productivity of the diverse range of crops that are commonly grown on these soils.

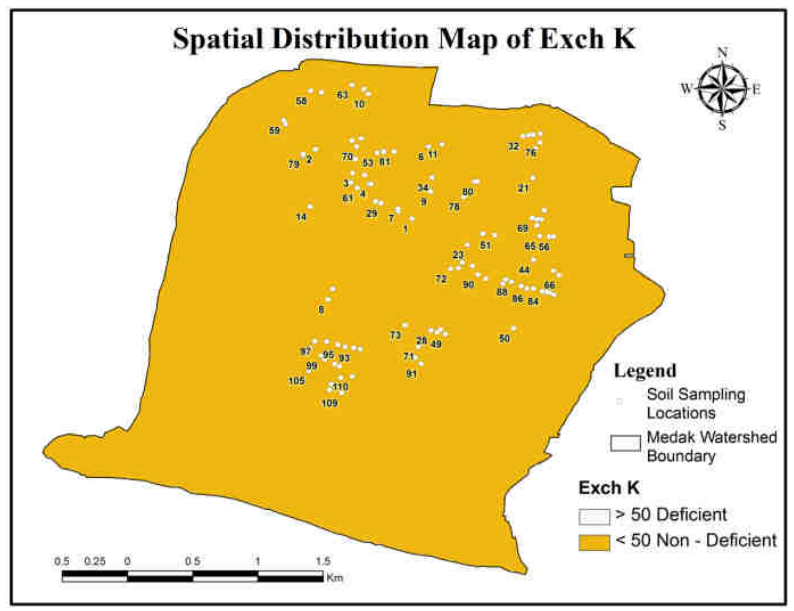

Fig.6

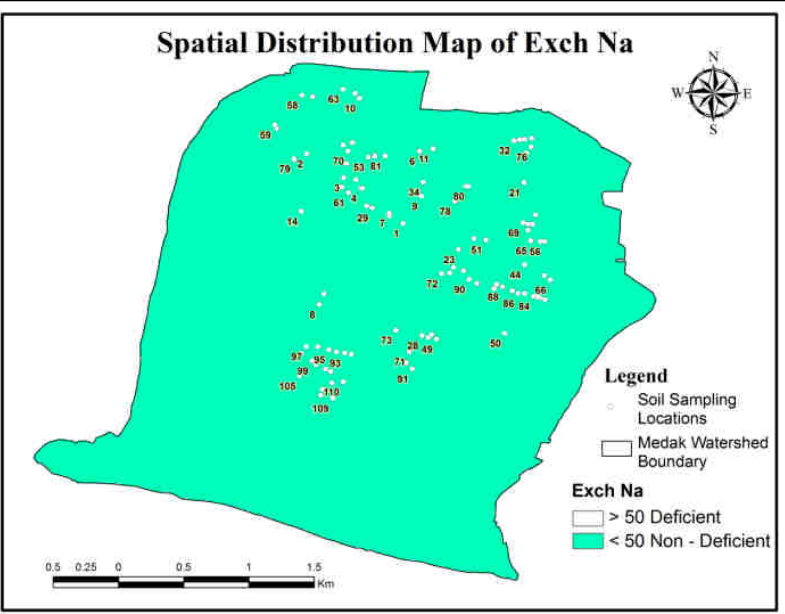

Fig.7

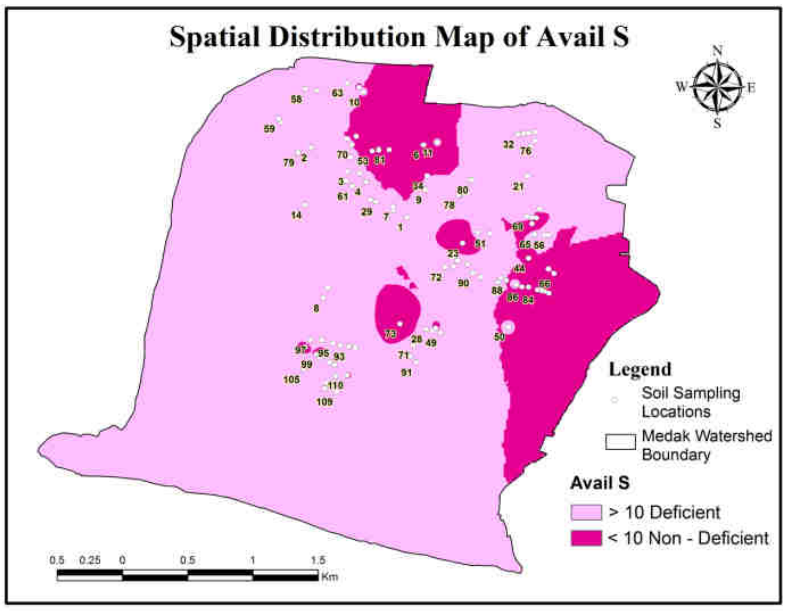

Fig. 8

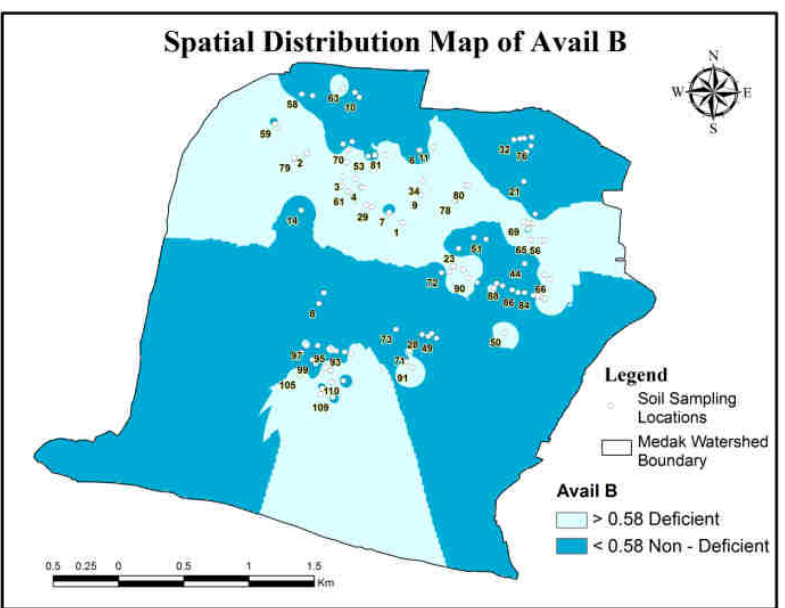

Fig. 9 


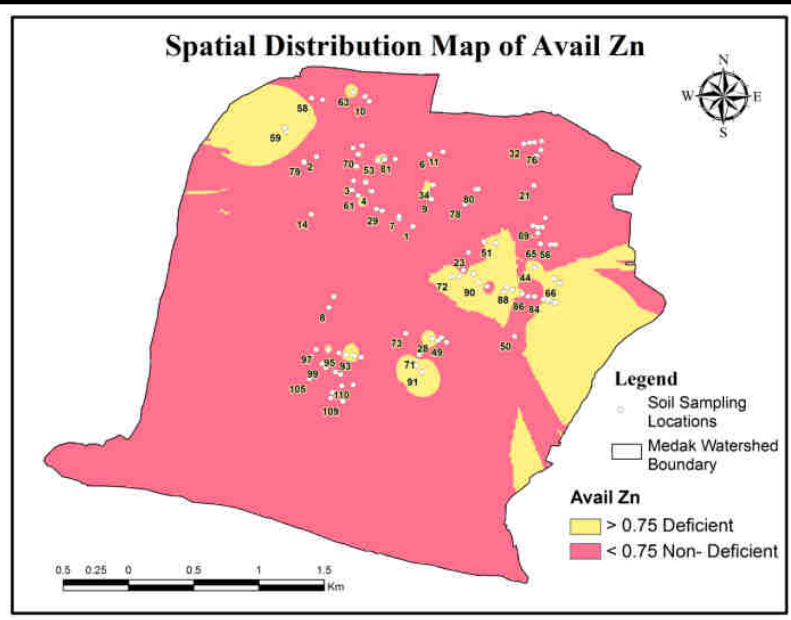

Fig. 10
For crop response study, on farm trials were planned and conducted with participation of farmer's. Based on the soil testing results, deficient nutrients were broadcasted and the response of various crops to balanced nutrient management over the farmer's inputs was studied and evaluated in terms of increase in yields of selected crops. Vegetables as tomato, chillies, turmeric and other common crops in the region as cotton, paddy and red gram were selected as test crops to carry out the trials.

Table 3 shows the detail information of the beneficiaries of balanced nutrition i.e. the farmer's on which the trial plots were conducted, crops selected, crop responses over both the treatments and enhancement in yields.

Table.3: Responses of crops to balanced nutrition over farmer's practice at Nagulapally-Konapur Model Watershed, Medak, Telanagana

\begin{tabular}{|c|l|c|c|c|c|c|}
\hline \multirow{2}{*}{ Sr. No } & \multirow{2}{*}{ Name of the Beneficiary } & Crops & \multicolumn{3}{|c|}{ Crop yield (kg/ha) } \\
\cline { 4 - 7 } & & & $\begin{array}{c}\text { Farmer's } \\
\text { Practice }\end{array}$ & $\begin{array}{c}\text { Balanced } \\
\text { Nutrition }\end{array}$ & $\begin{array}{c}\text { Yield } \\
\text { Increase }\end{array}$ & \% Increase \\
\hline 1 & Dakuri Anjanna & Tomato & 1200 & 1950 & 750 & 63 \\
\hline 2 & Saale Pandu & Chillies & 900 & 1320 & 420 & 47 \\
\hline 3 & Karkani Balaiah & Turmeric & 1510 & 1880 & 370 & 25 \\
\hline 4 & Mogudampally Veeranna & Cotton & 1700 & 2650 & 950 & 56 \\
\hline 5 & Patolla Baswaraj & Paddy & 1470 & 2100 & 630 & 43 \\
\hline 6 & Md Maqbul & Redgram & 900 & 1600 & 700 & 39 \\
\hline
\end{tabular}

Response of crops due to appication of S, B and $\mathrm{Zn}$ along with $\mathrm{N}, \mathrm{P}$ and $\mathrm{K}$ over farmer's practise ( application of only N,P and K) in tomato showed remarkable significant increase of $63 \%$ in yields of tomato. The vegetable yield increased from $1200 \mathrm{kgha}^{-1}$ with farmers practice to 1950 $\mathrm{kgha}^{-1}$ yields with balanced nutrition treatment. Chillies yielded $47 \%$ more with $\mathrm{FP}+\mathrm{S}, \mathrm{B}$ and $\mathrm{Zn}$ application than farmer's practice in fields of farmer Saale Pandu in Nagulapally village. The crop yields were recorded at $900 \mathrm{kgha}^{-1}$ for farmer's treatment with increasing to $1320 \mathrm{kgha}^{-1}$ in balanced nutrition treatment showing $420 \mathrm{kgha}^{-1}$ increase in yields. Turmeric cultivation increased the yield from $1510 \mathrm{kgha}^{-1}$ with farmer's practise treatment to $1880 \mathrm{kgha}^{-1}$ yields for balanced nutrient mangement. $25 \%$ increase in turmeric yields was recorded over farmer's practise. An impressive increase in yield was observed with Mogudampally Veeranna farmer in Nagulapally for cotton crop being benefited with $\mathbf{5 6 \%}$ increase in yields with balanced nutrition over farmer's practice (Figure 11). The cotton yield were recorded at $1700 \mathrm{kgha}^{-1}$ for traditional farmer's practise $2650 \mathrm{kgha}^{-1}$ Response with paddy crop benefited the Patolla Baswaraj farmer in Nagulapally village showing increase of $43 \%$ in crop yields recorded at $1470 \mathrm{kgha}^{-1}$ for farmer's treatment to $2100 \mathrm{kgha}^{-1}$ response to balanced nutrient management. Grain yield of redgram increased from $900 \mathrm{kgha}^{-1}$ to $1600 \mathrm{kgha}^{-1}$ showing increase in yields upto $\mathbf{3 9 \%}$ in Md Maqbul farmer in Konapur village of watershed. 


\section{Crop yield responses on balanced nutrition}

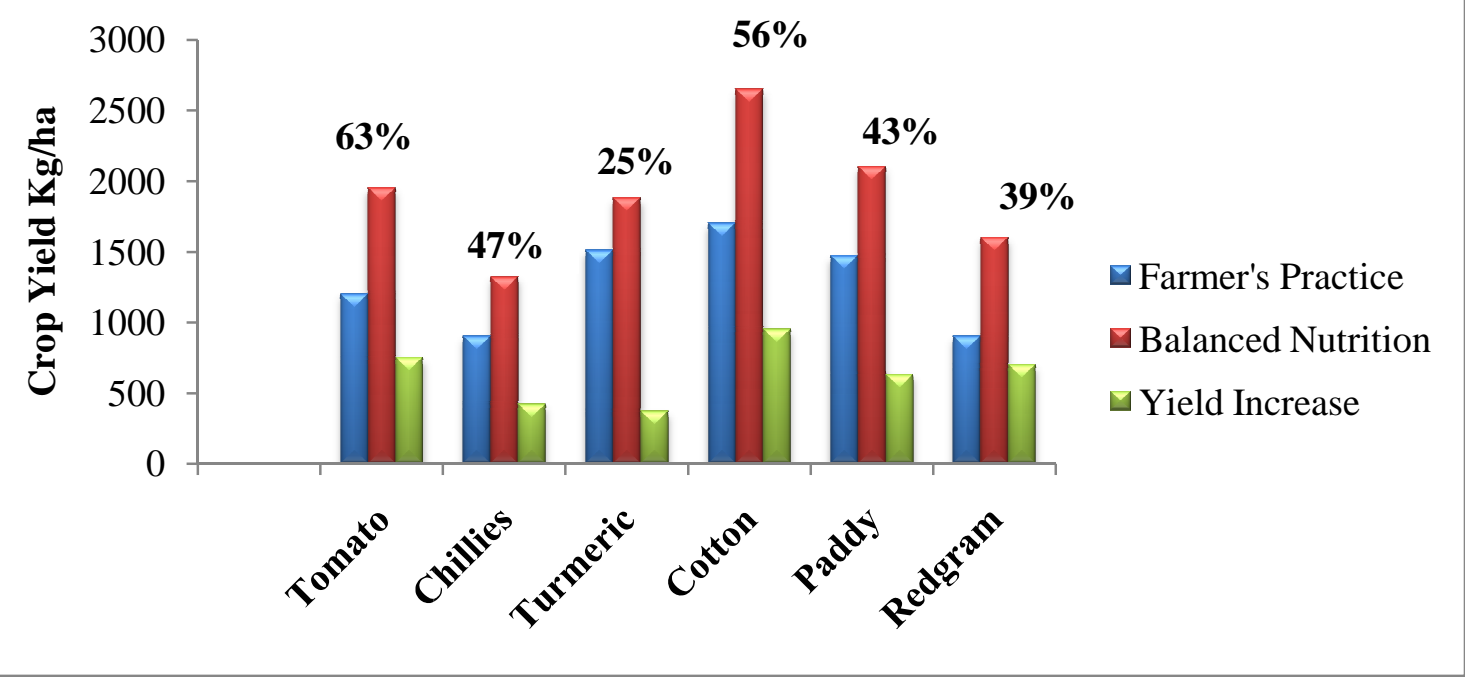

Fig.11: Graph showing significant yield responses of crops on balanced nutrition treatment over farmer's practice

Different crops responded differently to balanced nutrition showing maximum crop yield increase in tomato $(63 \%)$, cotton $(56 \%)$, chillies $(\mathbf{4 7 \%})$ followed by paddy $(\mathbf{4 3} \%)$, redgram $(\mathbf{3 9 \%})$ and minimum with turmeric $(25 \%)$.

\section{CONCLUSIONS}

Considering the results of analysis of all soil samples in Nagulapally-Konapur Watershed also, maximum deficiency was observed with Available Phosphorous (95\% of total farmers field were deficient), followed by Available sulphur (84\% deficiency), from 110 farmer's field, about $53 \%$ of soil samples were found deficient with Available Boron and the least deficiency of $42 \%$ soil samples out of 110 farmer's field was observed with Available $\mathrm{Zn}$. K and $\mathrm{Na}$ were found to be adequate in all the soil samples. Moreover, the application GIS techniques to democrate the locational distribution of the estimated fertility parameters of soil through spatial distribution maps proves to be an efficient tool to identify the deficient farmer's fields. Thus, GIS techniques can be used as an easy, simple and quick tool to identify the deficient farmer's fields with good accuracy. The results showed remarkable impressive yield responses to balanced nutrient management (FP + application of S, B and $\mathrm{Zn}$ micronutrients) as compared to farmer's practice treatment (application of $\mathrm{N}, \mathrm{P}$ and $\mathrm{K}$ ) and different responses were recorded with different crops. Thus, the results show that for sustained increase in productivity, the rain fed crops need application of $\mathrm{Zn}, \mathrm{B}$ and $\mathrm{S}$ along with $\mathrm{N}, \mathrm{P}$ and $\mathrm{K}$.

\section{REFERENCES}

[1] Ch. Srinivasarao, S.P.Wani, K.L. Sahrawat, T.J.Rego. G. Parthasaradhi, 2008. Zinc, boron and sulphur deficiencies are holding back the potential of rainfed crops in semi-arid India: Experiences from participatory watershed management, International Journal of Plant Production, 2 (1), 89-99.

[2] El-Swaify, S. A., Pathak, P., Rego, T. J. and Singh, S., 1985. Soil management for optimized productivity under rainfed conditions in the semi-arid tropics. Adv. Soil Sci., 1, 1-64.

[3] FAO, IFAD and WFP, 2014. The State of Food Insecurity in the World 2014.Strengthening the enabling environment for food security and nutrition. Rome, FAO.

[4] Girish Chander, Wani SP, Sahrawat KL and Jangawad LS. 2012. Balanced plant nutrition enhances rainfed crop yields and water productivity in Jharkhand and Madhya Pradesh states in India, Journal of Tropical Agriculture, 50(1-2), 24-29.

[5] Helmke, P.A., and D.L. Sparks., 1996. Lithium, sodium, potassium, rubidium, and cesium, In: Sparks, D.L. (ed.) Methods of soil analysis. Part 3, Chemical methods. SSSA Book Series No. 5. SSSA and ASA, Madison, WI, 551-574.

[6] Kanwar L. Sahrawat and Suhas P. Wani, 2013. Soil Testing as a Tool for On-Farm Fertility Management: Experience from the Semi-arid Zone of India. Communications in Soil Science and Plant Analysis, 44, (6),1011-1032.

[7] Keren, R., 1996. Boron. In D.L. Sparks (ed.) Methods of soil analysis, Part 3. Chemical methods, SSSA Book Series No. 5, SSSA and ASA, Madison, 
Wisconsin, USA: Soil Science Society of America and American Society of Agronomy, 603-626.

[8] K. L. Sahrawat, S. P. Wani, T. J. Rego, G. Pardhasaradhi and K. V. S. Murthy, 2007. Widespread deficiencies of Sulphur, Boron and Zinc in dry land soils of the Indian semi-arid tropics. Current Science, 93, (10), 1428-1432.

[9] Lindsay, W.L. and W.A. Norvell, 1978. Development of a DTPA soil test for zinc, iron, manganese, and copper, Soil Science Society of America Journal, 42, 421-428.

[10] Nelson DW and Sommers LE, 1996. Total Carbon, Organic Carbon, and Organic Matter, In Sparks, D.L. (ed.), Methods of Soil Analysis, Part 3, Chemical Methods, SSSA Book Series No. 5, SSSA and ASA, Madison, Wisconsin, USA: Soil Science Society of America and American Society of Agronomy, 9611010.

[11] Olsen, S.R. and L.E. Sommers, 1982. Phosphorus, In A.L. Page et al. (ed.) Methods of soil analysis. Part 2. 2nd ed. Agronomy Monogr. 9. ASA and SSSA, Madison, Madison, Wisconsin, USA: Soil Science Society of America and American Society of Agronomy, 403-430.

[12] Rego T.J., Wani SP, Sahrawat KL and Pardhasaradhi G. 2005. Macro-benefits from boron, zinc and sulfur application in Indian SAT: A step for Grey to Green Revolution in agriculture. Global Theme on Agroecosystems Report No. 16. Patancheru 502 324, Andhra Pradesh, India: International Crops Research Institute for the Semi-Arid Tropics (ICRISAT). 24 pp.

[13]Rego, T. J., Sahrawat, K. L., Wani, S. P. and Pardhasaradhi, G., 2007. Widespread deficiencies of sulfur, boron and zinc in Indian semiarid tropical soils: On-farm crop responses, Journal of Plant Nutrition, 30, 1569-1583.

[14] Sahrawat KL, Wani SP, Parthasaradhi G and Murthy KVS, 2010. Diagnosis of secondary and micronutrient deficiencies and their management in rain-fed agro ecosystems: Case study from Indian Semi-arid Tropics. Communications in Soil Science and Plant Analysis, 41,346-360.

[15] Srinivasarao, Ch., S.P. Wani, K.L. Sahrawat, K. Krishnappa, and B. K. Rajasekhara Rao, 2010. Effect of balanced nutrition on yield and economics of vegetable crops in participatory watersheds in Karnataka, Indian Journal of Fertilizers, 6, 39-42.

[16] Tabatabai, M.A., 1996. Sulfur. In: Methods of Soil Analysis - Part 3 - Chemical Methods (Ed.: D.L. Sparks) Madison, Wisconsin, USA: Soil Science Society of America, American Society of Agronomy, 921-960.
[17] Wani Suhas P. Girish Chander, Sahrawat Kl, Sreeenath Dixit, Venkateshwarlu B., 2013. Improved Crop productivity and rural livelihoods through balanced nutrition in the rainfed semi-arid tropics. Resilient Dryland Systems Report no. 58, Patancheru, Andhra Pradesh. India, International Crops Research Institute for the Semi-Arid Tropics, 1-36. 